\title{
An Econometric Analysis for the Behavior of the Bid-Ask Spread
}

\author{
H. de la Fuente-Mella*, R. Campos-Espinoza, \\ B. Silva-Palavecinos, D. Cademartori-Rosso \\ Facultad de Ciencias Económicas y Administrativas, Pontificia Universidad Católica de Valparaíso, \\ Escuela de Comercio, Valparaíso, Chile \\ Email: "hanns.delafuente@ucv.cl
}

Received July 2013

\begin{abstract}
Information asymmetries are an important element in the functioning of capital markets. An indirect means of measuring information asymmetry is through the spread of stock prices. The purpose of this paper is to identify the explanatory variables and the determinants of the bid-ask spread and to quantify the influence that the actors involved in the brokering of publically offered securities may have over the spread. The methodology used to model the time series for each of the analyzed companies is based on a time series from each of the observed econometric multivariate processes. The analysis shows a significantly negative relationship between the spread and the market-maker size, calculated in terms of both the equity and the stock portfolio; likewise, activity is measured by observing the amount offered for purchase and/or sale.
\end{abstract}

Keywords: Information Asymmetries; Econometric Modeling; Market Makers

\section{Introduction}

According to the economic theory associated with managing organizations, the separation of ownership and company leadership is common and does not automatically produce a corresponding alignment of objectives between management and investors. This situation produces an agency dilemma, which according to the Theory of Firms (Jensen \& Meckling, 1976), is strongly linked with asymmetries in corporate information.

An indirect means of measuring the information asymmetry is the bid-ask spread of stock prices. A larger spread is associated with greater information asymmetry (Amihud \& Mendelson, 1989; Coller \& Yohn, 1997; Kim \& Verrecchia, 1994; Bollen et al., 2004). The evidence suggests that the spread is smaller when there is more information available (Copeland \& Galai, 1983; Glosten \& Milgrom, 1985). Financial analysts draw greater spreads when they perceive that there is more information asymmetry (Kim \& Verrecchia, 1994; Coller \& Yhon, 1997). According to Venkatesh and Chiang (1986), analysts tend to expand the spread when they think that the information advantage for informed traders has increased.

The spread is of great interest to stockbrokers, agents, and regulators, as indicated by Huang and Stoll (1997). The presence of traders with superior levels of information leads to a positive spread even when the trade is risk-neutral, and there is zero expected profit (Glosten \& Milgrom, 1985). In other studies, the spread has been used to test for increased information asymmetry prior to the disclosure of such an event as the publication of results or the delivery of dividends (Venkatesh \& Chiang, 1986; Lesmond, 2005). Thus, in certain instances, the stock market is monopolistic (Benston \& Hagerman, 1974) because it has few significant actors and high entry barriers for new competition. The evidence additionally suggests that unsystematic risk is linked to the spread (Amihud \& Mendelson,

\footnotetext{
*Corresponding author.
}

1989).

Furthermore, even the type of intermediary matters, where the measurement of the spread is concerned. A vast amount of literature on the microstructure of the market addresses this theme from diverse points of view, such as the size of the intermediary's portfolio measured by personal assets, equity, and trading volume (Garman, 1976; Amihud \& Mendelson, 1980; Ho \& Stoll, 1980, 1981); thus, the size of the investment portfolio influences spread. In this sense, Hansch et al. (1998) indicate that the size of the stock list explains the volume of market transactions on the London Stock Exchange and the movement between the highest bid, the highest ask, and the spread has a high correlation with the changes in inventory. Furthermore, these researchers found that transactions among stockbrokers have a higher volume than do transactions that are open to the public. Moreover, Wahal (1997) showed that the changes in the spread of shares traded on the NASDAQ were larger (in magnitude) than certain fixed market-makers. In another study on the components of the bid-ask, Lin et al. (1995) found that for larger traders, the cost of the transaction process was less when the size of the transaction was greater. Thus, under competitive conditions the bid-ask measure the cost of operations without delay (Demsetz, 1968).

In this paper, the following hypotheses are made regarding the amount of influence that the size of the market-maker has over spread.

Hypothesis 1: The size of the market-maker, measured in terms of equity, affects spread; thus, the greater the markermaker's equity, the smaller the spread.

Hypothesis 2: The size of the market-maker, measured by their available stock portfolio, affects the spread; thus, the greater the stock portfolio of the market-maker, the smaller the spread.

Hypothesis 3: The level of the agent's activity, measured by the amount offered for purchase and/or sale, affects the spread; thus, the greater the amount offered to buy and/or sell, the small- 
er the spread.

The hypotheses above are validated by the Chilean Stock Market, a market that exhibits a high concentration of ownership. Thus, the average percentage of ownership of the largest shareholder of 40 stocks, which constitutes the selective stock price index or IPSA index (Indice de Precios Selectivo de Acciones, IPSA using its Spanish abbreviation), is $41 \%$, whereas in a random sample of 100 companies from Standard \& Poor's 500 Index, this percentage is only 9\% (Coloma, 2010). The average ownership among the first five shareholders of companies that constitute the IPSA is $69 \%$. Another aspect that characterizes the Chilean market is its lack of liquidity; Hernández and Parro (2004) note the difference between the causes of asymmetries of information and transaction costs.

To the sales stockbrokers and the agents that operate the 34 institutions in Chile, the spread is an important variable, constituting a transaction fee for using the stock market to complete the exchange of shares for cash rapidly. In turn, the spread has three components: order processing costs, inventory maintenance costs, and adverse selection costs (Chung \& Li, 2003; Chan \& Chung, 2011).

\section{Econometric Methodologies}

To evaluate the hypotheses, empirical evidence from the equity securities of 10 companies, separately and aggregately, was used. To ensure a heterogeneous example, the company selection was performed by taking into account the distribution of the IPSA companies based on industry, depending on the classification of level 1 by the North American Industry Classification System (NAICS). However, companies from the financial sector, from insurance, and from pension funds have been excluded because they have different regulatory frameworks. The following companies were chosen for this study on spread: Aguas Andinas SA. (Andina), CAP SA. (CAP), CENCOSUD SA. (Cencosud), CINTAC SA. (Cintac), SACI. Falabella (Falabella), GASCO SA. (Gasco), MADECO SA. (Madeco), MASISA SA. (Masisa), Multiexport Foods S.A. (Multifoods), and SALFACORP SA. (Salfacorp). The data were obtained from the Santiago Stock Exchange and from the Chilean National Bureau of Securities and Exchange, cover 2007 to 2010, and correspond to data equally spaced with an intraday frequency.

To identify and quantify the variables that explain the spread, an econometric multivariate time series model was developed in which the endogenous variable in the model is the spread (bid-ask). The exogenous variables in the model are as follows: quantity available for buy (quantity_buy), quantity available for sale (quantity_sell), the stockbroker making the buy offer (d_broker_buy), the stockbroker making the sell offer (d_broker_sell), indication of whether the offer (to buy or sell) is made by a stockbroker with influence, as measured by available portfolio (inventory_sell and inventory_buy) and assets (size_sell and size_buy). For the dichotomizing of the portfolio variables of personal actions and broker equity, an analysis was performed on the conglomerates of the $\mathrm{k}$ means based on the data for the entire period of study and obtained through the results of two groups defined, for convenience, as "large-size brokers" and "other-size brokers". For the selection of variables that were included in each of the delay models, the stepwise backward method was used based on the f-test, which measures the at-large contribution of the variance shown in the spread. Thus, the following relationships will be investigated for each company in the sample (Equation (1)):

Spread(bid_ask $)_{i t}=f\left(\right.$ quantity_buy $_{i t}$, quantity_sell ${ }_{i t}$, d_broker_buy ${ }_{i t}, d \_b r o k e r \_s e l l_{i t}$, inventory_buy ${ }_{i t}$, inventory_sell ${ }_{i t}$, size_buy ${ }_{i t}$, size_sell $_{i t}$ )

$i=1,2, \ldots, 10$ and $t=2007,2008,2009,2010$.

Finally, an aggregate analysis was made from all of the variables that contributed to the explanation of variance in the spread of the 10 models. This joint analysis method included an assessment of the individual contribution from each variable to each model, which is not combined. The contribution was calculated on the basis of unilateral statistics on the significance of individual regressive coefficients. To complete the evaluation of the hypotheses, we also made correlations between individual contributions and the size of stockbroker equity, the size of the portfolio, the brokerage volume and the average index during the last three patterns.

\section{Empirical Results}

A total of 10 different sets of variables were obtained, which helped to explain the spread with the highest degree of adjustment; each variable was evaluated separately. For example, the results of Table 1 showed the highest level of adjustment (with $56 \% \mathrm{R}^{2}$ ) for the spread of the shares of Aguas Andinas.

Table 1.

Results for the econometric multivariate modeling Aguas Andinas.

\begin{tabular}{ccccc}
\hline Variable & Coefficient & Std. Error & t-Statistic & Prob. \\
\hline AR(1) & .617367 & .005381 & 114.735400 & .0000 \\
C & .028105 & .000610 & 46.094950 & .0000 \\
D_BCI_BUY & .005240 & .001449 & 3.614753 & .0003 \\
D_CELFIN_BUY & .003559 & .000839 & 4.243625 & .0000 \\
D_CORPBANCA_BUY & .015764 & .000885 & 17.809310 & .0000 \\
D_MERRILL_SELL & -.009810 & .003004 & -3.265074 & .0011 \\
D_PENTA_SELL & -.014352 & .001630 & -8.804615 & .0000 \\
D_VALORESSEC_SELL & -.007451 & .001911 & -3.898063 & .0001 \\
D_YRARRAZ_SELL & .114172 & .001210 & 94.394180 & .0000 \\
INVENTORY_SELL & .002979 & .000687 & 4.338832 & .0000 \\
INVENTORY_BUY & -.009191 & .000786 & -11.695380 & .0000 \\
SIZE_BUY & .002163 & .000691 & 3.131776 & .0017 \\
SIZE_SELL & -.010149 & .000574 & .17 .680110 & .0000 \\
\hline
\end{tabular}


In general, all of the models had an adequate criterion for information (based on the statistics from Akaike, Schwarz and Hannan-Quinn). However, the models suffered from an autocorrelation problem, which was solved by incorporating a single autoregressive order 1 . With this model, the best adjustment levels were achieved by having different sets of variables (see Table 2) with respect to both quantity and type of variable. Thus, for certain companies (such as CAP and Cintac), many stockbroker variables were included, but few were related to the transaction or broker size. For other companies (such as Aguas Andina or Gasco), the contribution of the dummy variables of stockbrokers was much less noticeable, and the statistical contribution to the explanation of the spread by the other variables was greater. Another notable feature is that the number of variables linked to the sales transactions was greater than the number of those related to the buy offer. Associated with this differentiation of variables, all of the coefficients of the variable "buy transactions" were positive versus those associated with the variable "sales transactions", which were negative. This result is consistent with economic-financial theory.

Moreover, between $21 \%$ and $70 \%$ of the variability of the endogenous variable is explained by the variability of the exogenous variable, depending on the equity title (see Table 2). The significance of the degree of comprehensive and individual explanations of the models is higher than 95\% and, in many other cases, is higher than 99\%. In Table 3, the $p$-value score of each coefficient (based on the $t$-test) is zero in most cases. From the results shown in Tables $\mathbf{3}$ and $\mathbf{4}$, it is possible to see that the variability of the equity, the size of the portfolio, and the activity level (quantity supplied) of the market-maker significantly influenced (5\%) the spread in the majority of the models, validating the three hypotheses. Nevertheless, in the three models, only one of the three variables significantly influenced the spread: CAP, Cintac, and Salfacorp. With the first two, the explanation of variance in the spread is offset by the inclusion of a greater number of dummy variables that identify stockbrokers, whereas in Salfacorp, few variables contributed to the explanation of the spread; therefore, its adjustments are the lowest (21\%).

In assessing together the spread variability across the 10 constructed models, we see that the leading autoregressive category was the most relevant. Table 4 shows that this contribution is far greater than the relevance of the remaining variables. This result is primarily due to the temporary nature of the proposed models, leading to a high stochastic volatility in the intraday data (Engle, 1982; Bollerslev, 1986; Triaccaa, 2008; Afonsoab \& Jallesbc, 2012). The assessment also shows that the variables related to the size and capacity of the intermediaries (related to Hypothesis 1 and Hypothesis 2) have more influence than the number of shares offered (related to Hypothesis 3) but still much less than the constant and the autoregressive categories. The rate of the dummy variable for identifying stockbrokers was individually low, although certain models were exceptionally high, both individually (31\%) and as a whole (67\%).

In assessing the individual contribution that relates the variables to the stockbroker, Larrain Vial, Celfin Capital, Ugarte y Cía, and Penta are observed in most models (see Table 5). These 4 stockbrokers account for almost $30 \%$ of the market share (based on the size of the equity, size of the portfolio and trading volume). However, the stockbrokers who contributed relatively more in the various models were Yrarrázaval y Cía., Valores Security, and Consorcio. It is also noted that the variables of the stockbrokers in sales transactions provided more opportunities to explain the spread (69 times versus 119), especially with the stockbrokers Deutsche Securities, Molina y Swett, BBVA, or BCI. However, the overall average contribution for sales transactions was slightly lower (1.82\%) than for buy transactions (2.16\%).

Moreover, a slight tendency can be observed between the ef-

Table 2.

A summary of the types of variables that allow the greatest multivariate adjustment.

\begin{tabular}{cccccccc}
\hline & \multicolumn{2}{c}{ Variables Related to the Spread } & Stockbroker Variables & Variable & Grade of \\
\hline Company & Quantity Supplied & Broker Size & Inventory Size & Buy & Sell & Totals & Adjustment \\
\hline Andina & - & buy, sell & buy, sell & 4 & 3 & 11 & $56 \%$ \\
CAP & sell & - & - & 4 & 26 & 31 & $41 \%$ \\
Cencosud & sell & sell & sell & 10 & 11 & 24 & $34 \%$ \\
Cintac & - & - & sell & 8 & 24 & 33 & $45 \%$ \\
Falabella & sell & sell & sell & 13 & 21 & 37 & $44 \%$ \\
Gasco & buy, sell & buy, sell & sell & 9 & 1 & 15 & $37 \%$ \\
Madeco & buy, sell & sell & sell & 8 & 10 & 22 & $70 \%$ \\
Masisa & sell & buy, sell & sell & 5 & 20 & 29 & $39 \%$ \\
Multifoods & buy & sell & - & 6 & 2 & 10 & $42 \%$ \\
Salfacorp & - & - & sell & 2 & 2 & 5 & $21 \%$ \\
& 3 buy, 6 sell & 3 buy, 7 sell & 1 buy, 8 sell & 69 & 120 & 217 & \\
\hline
\end{tabular}

Table 3.

The statistics that summarize the $p$-value of the multivariate coefficients.

\begin{tabular}{ccccccc}
\hline & AR(1) & Constant & Size of Equity & Size of Inventory & Quantity & Brokers \\
\hline Minimum & $.00 \%$ & $.00 \%$ & $.00 \%$ & $.00 \%$ & $.00 \%$ & $.00 \%$ \\
First quartile & $.00 \%$ & $.00 \%$ & $.00 \%$ & $.00 \%$ & $.00 \%$ & $.00 \%$ \\
Median & $.00 \%$ & $.00 \%$ & $.00 \%$ & $.00 \%$ & $.00 \%$ & $.00 \%$ \\
Third quartile & $.00 \%$ & $.00 \%$ & $.00 \%$ & $.00 \%$ & $.04 \%$ & $.00 \%$ \\
Maximum & $.00 \%$ & $.00 \%$ & $7.71 \%$ & $.00 \%$ & $27.88 \%$ & $16.79 \%$ \\
\hline
\end{tabular}


Table 4.

Summary of the individual contribution of the type of variables in each regressive model.

\begin{tabular}{|c|c|c|c|c|c|c|}
\hline & $\operatorname{AR}(1)$ & Constant & Size of Equity & Size of Inventory & Quantity & Stockbrokers (Collectively) \\
\hline Minimum & $22.70 \%$ & $5.25 \%$ & $1.41 \%$ & $2.30 \%$ & $1.90 \%$ & $1.40 \%(3.0 \%)$ \\
\hline Median & $46.82 \%$ & $13.02 \%$ & $4.70 \%$ & $4.88 \%$ & $2.23 \%$ & $3.50 \%(35.5 \%)$ \\
\hline Maximum & $81.07 \%$ & $20.63 \%$ & $7.12 \%$ & $7.07 \%$ & $3.00 \%$ & $30.64 \%(67.0 \%)$ \\
\hline
\end{tabular}

Table 5.

Average contribution of the stockbroker variables.

\begin{tabular}{|c|c|c|c|c|c|c|c|}
\hline \multicolumn{3}{|c|}{ Aggregate Statistics (10 models) } & \multicolumn{2}{|c|}{ Average Contribution } & \multicolumn{2}{|c|}{ Times That it Contributed } & \multirow[b]{2}{*}{ Relative Size of the Market } \\
\hline Stockbroker & Average Contribution & Times that it Contributed & Buyer & Seller & Buyer & Seller & \\
\hline Yrarrázaval y Cía. & $6.78 \%$ & 5 & $1.88 \%$ & $.63 \%$ & 3 & 2 & $.18 \%$ \\
\hline Valores Security & $4.33 \%$ & 5 & $8.29 \%$ & $1.70 \%$ & 2 & 3 & $4.19 \%$ \\
\hline Consorcio & $3.86 \%$ & 7 & $3.86 \%$ & & 7 & & $2.89 \%$ \\
\hline BCI & $3.06 \%$ & 7 & $.51 \%$ & $3.49 \%$ & 1 & 6 & $7.41 \%$ \\
\hline BICE & $2.91 \%$ & 5 & & $2.91 \%$ & & 5 & $3.20 \%$ \\
\hline Banchile & $2.83 \%$ & 5 & $2.31 \%$ & $3.60 \%$ & 3 & 2 & $10.03 \%$ \\
\hline Corpbanca Corred. & $2.66 \%$ & 9 & $2.62 \%$ & $2.78 \%$ & 7 & 2 & $7.96 \%$ \\
\hline FIT Research & $2.49 \%$ & 4 & & $2.49 \%$ & & 4 & $1.30 \%$ \\
\hline Munita C\&C & $2.18 \%$ & 6 & $4.93 \%$ & $.80 \%$ & 2 & 4 & $.38 \%$ \\
\hline Larrain Vial & $2.04 \%$ & 10 & $1.27 \%$ & $2.82 \%$ & 5 & 5 & $13.89 \%$ \\
\hline Celfin Capital & $1.94 \%$ & 10 & $1.80 \%$ & $2.08 \%$ & 5 & 5 & $8.47 \%$ \\
\hline EuroAmerica & $1.87 \%$ & 5 & $.56 \%$ & $2.74 \%$ & 2 & 3 & $2.99 \%$ \\
\hline Penta & $1.84 \%$ & 10 & $.71 \%$ & $2.33 \%$ & 3 & 7 & $3.31 \%$ \\
\hline NEVASA & $1.64 \%$ & 8 & $.47 \%$ & $2.35 \%$ & 3 & 5 & $1.73 \%$ \\
\hline Tanner & $1.63 \%$ & 7 & $1.71 \%$ & $1.57 \%$ & 3 & 4 & $1.08 \%$ \\
\hline Deutsche Securit. & $1.59 \%$ & 8 & $.07 \%$ & $1.81 \%$ & 1 & 7 & $3.18 \%$ \\
\hline BBVA & $1.59 \%$ & 6 & & $1.59 \%$ & & 6 & $2.07 \%$ \\
\hline Santander SACB & $1.51 \%$ & 4 & $.28 \%$ & $2.73 \%$ & 2 & 2 & $5.26 \%$ \\
\hline Scotia CB & $1.25 \%$ & 5 & & $1.25 \%$ & & 5 & $.63 \%$ \\
\hline Molina \& Swett & $1.24 \%$ & 6 & & $1.24 \%$ & & 6 & $.29 \%$ \\
\hline Lira y Cía. & $1.21 \%$ & 5 & $.35 \%$ & $1.79 \%$ & 2 & 3 & $.57 \%$ \\
\hline Jaime Larraín & $1.19 \%$ & 8 & $.93 \%$ & $1.45 \%$ & 4 & 4 & $1.59 \%$ \\
\hline Merrill Lynch & $1.03 \%$ & 6 & $-.02 \%$ & $1.23 \%$ & 1 & 5 & $3.01 \%$ \\
\hline Valenzuela Laf. & $1.00 \%$ & 5 & $-.04 \%$ & $1.26 \%$ & 1 & 4 & $.22 \%$ \\
\hline FYNSA & $1.00 \%$ & 3 & & $1.00 \%$ & & 3 & $.63 \%$ \\
\hline Cruz del Sur & $.84 \%$ & 3 & & $.84 \%$ & & 3 & $.27 \%$ \\
\hline Ugarte y Cía. & $.84 \%$ & 10 & $.63 \%$ & $.98 \%$ & 4 & 6 & $2.42 \%$ \\
\hline Etchegaray & $.72 \%$ & 6 & $.58 \%$ & $1.42 \%$ & 5 & 1 & $.73 \%$ \\
\hline MBI & $.68 \%$ & 3 & & $.68 \%$ & & 3 & $11.88 \%$ \\
\hline BancoEstado & $.65 \%$ & 3 & $.63 \%$ & $.71 \%$ & 2 & 1 & $1.74 \%$ \\
\hline IM Trust & $.65 \%$ & 4 & $.11 \%$ & $.83 \%$ & 1 & 3 & $3.40 \%$ \\
\hline Average (total) & $1.94 \%$ & (188) & $2.16 \%$ & $1.82 \%$ & (69) & (119) & (100.00\%) \\
\hline
\end{tabular}

fects of the stockbroker size on the contribution of the spread. The first third of the stockbrokers in Table 5 (separated by the horizontal line) accounted for $60 \%$ of the market, while the other two blocks each share approximately $20 \%$ (note that stockbrokers are ranked by their average total contribution).

A better way to observe the relationship between the broker size and the contribution in the models is based on the correlations shown in Table 6 between the indicators of the contributions (total and average) and the number of times that these variables appear in the stockbroker's finances versus the indicators of size and share of the market. From this table, a high correlation (approximately 86\%) is observed between the number of transactions that the stockbroker variables express on the spread and the index "share of the market and broker size". This evidence supports Hypotheses 1 and 2. Therefore, according to this correlation indicator, the stockbroker does not play an irrelevant role in the selection of variables that explain the spread; on the contrary, both processes are highly correlated.

\section{Conclusion}

Using an econometric multivariate analysis, we can conclude that the coefficients from buys (positive) and sales (negative) are supported by economic theory. The negative relationship, which is statistically significant, between the quantities available for sale and the spread could have three causes: 1) market pressure associated with the buy and sell forces; 2) the asymmetry of the information used for investment; or 3) different stockbrokers using their own inventories of possible actions to prepare for potential offers and demands.

This evidence indicates that a high level of activity among stockbrokers, as measured by the quantity supplied, negatively affects the spread, thus validating hypothesis 3 . In the multivariate models used in this study, the broker size was measured based on equity and the available portfolio, collectively explaining spread in a statistically significant way (5\% chance of error). This evidence validates hypotheses 1 and 2 from this 
Table 6.

Correlation of the parameters associated with the variables and characteristics of stockbrokers.

\begin{tabular}{|c|c|c|c|c|}
\hline & Corporate Equity & Inventory & Volume of Transactions & Market Share and Size \\
\hline Total Contribution & $34 \%$ & $-5 \%$ & $26 \%$ & $-9 \%$ \\
\hline Average Contribution & $23 \%$ & $31 \%$ & $-7 \%$ & $51 \%$ \\
\hline Times Contributed & $17 \%$ & $-12 \%$ & $70 \%$ & $31 \%$ \\
\hline Average Contribution in Buyer Offers & $-2 \%$ & $20 \%$ & $14 \%$ & $0 \%$ \\
\hline Average Contribution in Seller Offers & $68 \%$ & $37 \%$ & $-1 \%$ & $77 \%$ \\
\hline Times Contributed Offer as Buyer & $19 \%$ & $6 \%$ & $72 \%$ & $86 \%$ \\
\hline Times Contributed Offer as Seller & $-8 \%$ & $42 \%$ & $50 \%$ & $87 \%$ \\
\hline
\end{tabular}

research.

Finally, we observe that further and interesting research work will eventually be developed toward new indicators that allow the quality of information to be measured. This measurement will involve the formulation of an index based on the items proposed by Haat et al. (2006) and based on the index proposed by Botosan (1997). In addition, this study can be expanded to include other companies from the Chilean market, comprising various industrial sectors.

\section{REFERENCES}

Afonsoab, A., \& Jallesbc, J. T. (2012). Fiscal volatility, financial crises and growth. Applied Economics Letters, 19, 1821-1826. http://dx.doi.org/10.1080/13504851.2012.667531

Amihud, Y., \& Mendelson, H. (1980). Dealership markets market making with inventory. Journal of Financial Economics, 8, 21-53.

Amihud, Y., \& Mendelson, H. (1989). The effects of beta, bid-ask spread, residual risk, and size on stock returns. The Journal of Finance, 44, 479-486. http://dx.doi.org/10.1111/j.1540-6261.1989.tb05067.x

Benston, G. J., \& Hagerman, R. L. (1974). Determinants of bid-asked spreads in the over-the-counter market. Journal of Financial Economics, 1, 353-364. http://dx.doi.org/10.1016/0304-405X(74)90014-2

Bollen, N., Smith, T., \& Whaley, R. (2004). Modeling the bid/ask spread: Measuring the inventory-holding premium. Journal of Financial Economics, 72, 97-141.

http://dx.doi.org/10.1016/S0304-405X(03)00169-7

Bollerslev, T. (1986). Generalized autoregressive conditional heterocedasticity. Journal of Econometrics, 31, 307-327. http://dx.doi.org/10.1016/0304-4076(86)90063-1

Botosan, C. A. (1997). Disclosure level and the cost of equity capital. The Accounting Review, 72, 323-349.

Chan, K., \& Chung, P. (2011). Asymmetric price distribution and bidask quotes in the stock options market draft. http://www.apjfs.org/conference/2011/cafmFile/2-4.pdf

Chung, K., \& Li, M. (2003). Adverse-selection costs and the probability of information-based trading. The Financial Review, 38, 257-272. http://dx.doi.org/10.1111/1540-6288.00045

Coloma, F. (2010). Desafíos de la regulación de gobiernos corporativos en Chile. Superintendente de Valores y Seguros. Presentación Jornada de Gobierno Corporativo Centro de Gobierno Corporativo Universidad Católica, November 18, 2010.

Coller, M., \& Yohn, T. (1997). Management forecasts and information asymmetry: An examination of bid-ask spreads. Journal of Accounting Research, 35, 181-191. http://dx.doi.org/10.2307/2491359

Copeland, T., \& Galai, D. (1983). Information effects on the bid-ask spread. Journal of Finance, 38, 1457-1469. http://dx.doi.org/10.1111/j.1540-6261.1983.tb03834.x

Demsetz, H. (1968). The costs of transacting. Quarterly Journal of Economics, 82, 33-53. http://dx.doi.org/10.2307/1882244

Engle, F. R. (1982). Autoregressive conditional heterocedasticity whit estimates of the variance of United Kingdom inflation. Econometrica, 50, 987-1008. http://dx.doi.org/10.2307/1912773

Garman, M. B. (1976). Market microstructure. Journal of Financial Economics, 3, 257-275.

http://dx.doi.org/10.1016/0304-405X(76)90006-4

Glosten, L., \& Milgrom, P. (1985). Bid, ask and the transaction prices in a specialist market with heterogeneously informed traders. Journal of Financial Economics, 14, 71-100. http://dx.doi.org/10.1016/0304-405X(85)90044-3

Haat, H. M., Mahenthiran, S., Rahman, A. R., \& Hamid, A. N. (2006). Agency costs as a factor in the suspension of companies from the Kuala Lumpur stock exchange. Journal of Contemporary Accounting and Economics, 2, 99-121. http://dx.doi.org/10.1016/S1815-5669(10)70018-7

Hansch, O., Naik, N., \& Viswanathan, S. (1998). Do inventories matter in dealership markets? Evidence from the London stock exchange. Journal of Finance, 53, 1623-1656. http://dx.doi.org/10.1111/0022-1082.00067

Hernández, L., \& Parro, F. (2004). Sistema financiero y crecimiento económico en Chile, Banco Central de Chile, Working Paper No. 291, Santiago, Chile.

Ho, T., \& Stoll, H. (1980). On dealer markets under competition. Journal of Finance, 35, 259-267.

http://dx.doi.org/10.1111/j.1540-6261.1980.tb02153.x

Ho, T., \& Stoll, H. (1981). Optimal dealer pricing under transactions and return uncertainty. Journal of Financial Economics, 9, 47-73. http://dx.doi.org/10.1016/0304-405X(81)90020-9

Huang, R., \& Stoll, H. (1997). The components of the bid-ask spread: A general approach. The Review of Financial Studies, 10, 995-1034. http://dx.doi.org/10.1093/rfs/10.4.995

Kim, O., \& Verrecchia, R. E. (1994). Market liquidity and volume around earnings announcements. Journal of Accounting and Economics, 17, 41-67. http://dx.doi.org/10.1016/0165-4101(94)90004-3

Jensen, M., \& Meckling, W. (1976). Theory of the firm: Managerial behavior, agency costs and ownership structure. Journal of Financial Economics, 3, 305-360.

http://dx.doi.org/10.1016/0304-405X(76)90026-X

Lesmond, D. (2005) Liquidity of emerging markets. Journal of Financial Economics, 77, 411-452.

http://dx.doi.org/10.1016/j.jfineco.2004.01.005

Lin, J., Sanger, G., \& Booth, G. G. (1995). Trade size and components of the bid ask spread. Review of Financial Studies, 8, 1153-1183. http://dx.doi.org/10.1093/rfs/8.4.1153

Triaccaa, U. (2008). Erratum to on the variance of the error associated to the squared return as proxy of volatility. Applied Financial Economics Letters, 4, 417. http://dx.doi.org/10.1080/17446540701765233

Venkatesh, P. C., \& Chiang, R. (1986). Information asymmetry and the dealer's bid-ask spread: A case study of earnings and dividend announcements. Journal of Finance, 41, 1089-1102. http://dx.doi.org/10.1111/j.1540-6261.1986.tb02532.x

Wahal, S. (1997). Entry, exit, market makers and the bid-ask spread. The Review of Financial Studies, 10, 871-901. http://dx.doi.org/10.1093/rfs/10.3.871 